Human Resource Development Practices and Organizational Performance: Evidence From De United Food Industries Limited Ota Ogun State, Nigeria

Sholesi, Olayinka Yusuf

To Link this Article: http://dx.doi.org/10.6007/IJARBSS/v11-i4/9627

DOI:10.6007/IJARBSS/v11-i4/9627

Received: 01 February 2021, Revised: 13 March 2021, Accepted: 30 March 2021

Published Online: 14 April 2021

In-Text Citation: (Sholesi, 2021)

To Cite this Article: Sholesi, O. Y. (2021). Human Resource Development Practices and Organizational Performance: Evidence From De United Food Industries Limited Ota Ogun State, Nigeria. International Journal of Academic Research in Business and Social Sciences, 11(4), 75-88.

Copyright: @ 2021 The Author(s)

Published by Human Resource Management Academic Research Society (www.hrmars.com)

This article is published under the Creative Commons Attribution (CC BY 4.0) license. Anyone may reproduce, distribute, translate and create derivative works of this article (for both commercial and non-commercial purposes), subject to full attribution to the original publication and authors. The full terms of this license may be seen at: http://creativecommons.org/licences/by/4.0/legalcode

Vol. 11, No. 4, 2021, Pg. 75 - 88

Full Terms \& Conditions of access and use can be found at http://hrmars.com/index.php/pages/detail/publication-ethics 


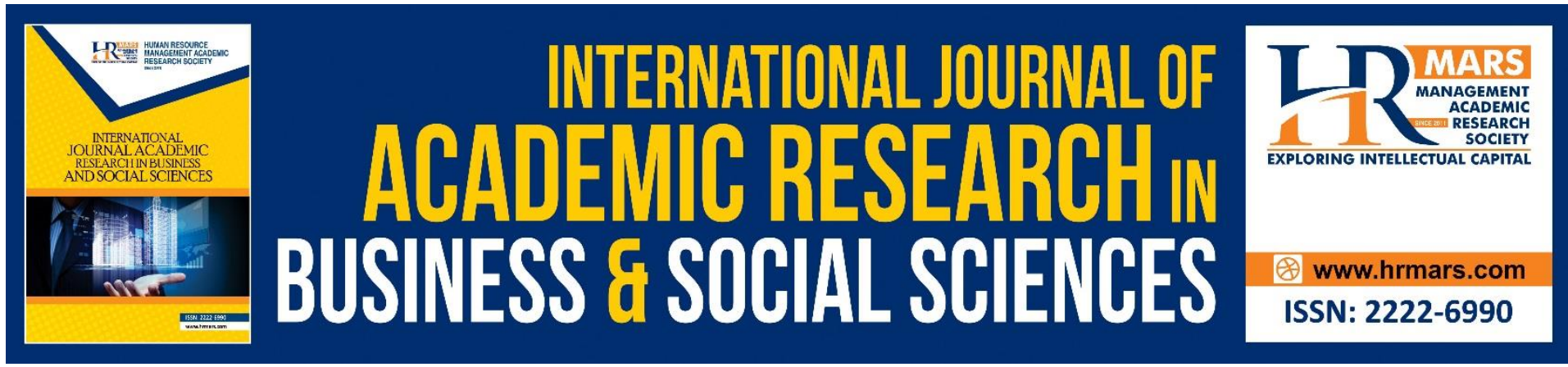

\title{
Human Resource Development Practices and Organizational Performance: Evidence From De United Food Industries Limited Ota Ogun State, Nigeria
}

\author{
Sholesi, Olayinka Yusuf \\ Kolawole, Ibukun Olorunisola PhD, Department of Industrial Relations and Human Resource \\ Management, Faculty of Management Science Lagos State University, Ojo, Lagos, Nigeria \\ Email: contactyinkasho@yahoo.com,kolawole@lasu.edu.ng
}

\begin{abstract}
The decline in organization's investment in Human Resources Development practices as continued to affect organizational performance. This study examined Human Resource Development and organizational Performance at De United food industries limited located in Ota Ogun State, Nigeria. The study adopted the survey research method, using descriptive research design. Systematic random sampling technique was used to draw sample from the population. Two hundred and forty eight (248) copies of the questionnaire were distributed and two hundred and four (204) copies were duly completed by the employees of De United food and industries limited. Two hypothesis were tested using regression, with the aid of SPSS (20.0) version. The results shows that 46.1 . \% variation in organizational performance is explained by training and development, which implies that as employee training and development improves organizational performance is enhanced. The result also revealed that organizational learning accounts for $1.7 \%$ of organizational performance

Based on the findings the study recommended that organizations should take training and development of employees seriously by imbibing the culture of budgeting for training at the beginning of every financial year. Finally organizations should view training broadly as a way of creating intellectual capital to enhance organizational performance.
\end{abstract}

Keywords: Human resource development, Organizational Performance and Organizational Learning, Training, Development.

\section{Introduction}

The world doesn't remain the same rather it keeps on changing. Almost on daily basis, there are new development which may be technological, process improvement, new ideas, new products and so on as a result of which business environment is facing considerable changes. On the other hand, globalization is another problematic area for a number of industries in developing countries due to increased competition with regards to the product quality, services, price, delivery among others and as such organizations require to learn more quickly than competitors to remain distinctive and sustainable (Garavan, 2016). Organizations are 
nothing but groups of people working to achieve some predefined goals and mission. Therefore these are the people who need organizational focus to build their skills and capabilities to enable organizations cope with the challenges of globalization and become more effective. People run machines, machines don't run people, so investment in people leads to productivity, the most valuable of all capital is that invested in human beings.

To this end, Olayemi (2012) stated that effective investment in human capital is a key component of long run economic growth, improved productivity and organizational performance. Hence organizations quest for an important source of efficiency and competitive advantage associated with improved corporate performance directs them to develop their human resources strategically.

Human beings make things happen and effective human beings make things happen effectively. Human resource development means providing your employee with training and development programmes of various types that are relevant to their respective roles, duties and responsibilities.

Mohammed (2016) posits that the success and progress of an organization depend on its ability to maximally explore the talent and potentials of its strategic workforce. This is more likely to be achieved through purposeful human resources development capability of an organization. This study argues in favour of investing in human resources development practices as a prerequisite for improving organizational performance.

\section{Statement of the Problem}

Several studies have been carried out on human resource development, for instance (Daniel, 2012; Khalid, 2014; Hassan, 2014; Roselin; 2014) among others. Most of the studies reviewed, revealed that most organizations don't usually have an annual training budget and that organizations don't invest much in learning activities and this affects performance.

Previous literatures (Ezeanokwasam 2014; Agwu and Ogiriki, 2014; Obi - Anike and Ekwe, 2014;Garavan, Shanahan, Carbery and Watson, 2016; Nolan and Garavan,, 2016; Nawaz and Pangil, 2016) also revealed that there is lesser business linkage between training institutions and the corporate sector, which is expedient to enhance performance. The previous literatures also revealed that many organizations don't engage in organizational learning, neither do they properly identify training need, which is the gap between expected and actual performance before embarking on a training programme. All these is affecting overall organizational performance at De United Food Industries Limited.

\section{Research Objectives}

The main objective is to examine the effect of Human Resources Development (HRD) on organizational performance.

Other specific objectives of the research are as follows:

1. To examine the effect of training and development on organizational performance.

2. To investigate the effect of organizational learning on organizational performance.

\section{Research Questions}

1. To what extent will training and development have effect on organizational performance?.

2. What is the effect of organizational learning on organizational performance? 


\section{Research Hypotheses}

1. $\mathbf{H}_{\mathbf{o}}$ : Training and development as no effect on organizational perfomance

2. $\mathbf{H}_{\mathbf{o}}$ : Organizational learning has no effect on organizational performance

\section{Literarture Review}

The concept of Human Resource Development (HRD) and Organizational Performance have been explored by several authors in recent years. This conceptual review would examine the concept of Human resource development and Organizational performance. Human Resource Development (HRD) is increasingly one of the most comprehensively researched areas in the broader sphere of human resources management (Garavan, Cross, Wilson, and Carbery, 2012). Researchers, commentators and policy makers have stressed the importance of investment in Human Resources Development (HRD) to enhance the qality of human capital and create sustainable competitive advantage. There is a large and growing body of literature that shows a positive linkage between human resources development and organizational performance.

Increasing employee's skills and abilities are expetced to create future returns through increased productivity and business performance (Shih, Chiang, \& Hus, 2006). For example, Lee (2003) argued that (HRD) Human Resources Development practice is about addressing the underlying assumptions of human conditions and influencing human conditions. Several researches (Okoye and Ezejiofor, 2013; Ezeanokinasa, 2014; Agwu and Ogiriki,2014) among Others point to the fact that Human Resources Development (HRD) is a vital strategy for the improvement of employees for the attainment of organizational performance of enhanced products and service delivery for the survival and growth of any enterprise, either in public or private sector. According to Harbison and Meyers (1964), Human Resources Development (HRD) is the process of increasing the knowledge, skills and capabilities of all people in a given society or organization. Swanson (2001) opined that Human Resources Development (HRD) is a process of developing and/ or unleashing human expertise through Organization Development (OD) and personnel Training and Development ( $\&$ \& $)$ for the purpose of improving performance.

This according to them is done through the process of formal education on the job through systematic and informal training programme. And also for self-development on the part of individual employee through personal initiative, arising from his or her willingness to acquire new ideas for higher productivity.

Garavan (2002) contended that HRD is used in many contexts and applies widely differing activities. What appears to be a comprehensive conceptualization of HRD was given by Rodrigues and Chinchokar (2005) as the process of improving, moulding and changing skills, knowledge, creative abilities, aptitude, attitude, values and commitment based on present and future job and organizational requirements for improved productivity in the work place. The conceptualization of HRD by the various scholars above point to the fact that it is a medium by which employees in an organization are transformed from their present state to a desired state of affairs in the area of improved skills and knowledge through training (capacity building) for the purpose of achieving organizational goals and Objectives. Rapidly changing technology require that employees posses the knowledge and skills necessary to cope with new process and production techniques. 
Organizational performance is one of the most broadly and extensively used dependent variable in organizational studies today, and yet at the same time it remains one of the most imprecise and loosely defined constructs (Roger \& Wright, 1998). The focus of attention on the construct has been concerned almost entirely with financial measures of performance. Conceptually, organizational performance has been defined as the comparison of the value produced by a company and the value owners are expected to receive from the company (Alchian \& Demsetz, 1972).

According to Cook and Hunsaker (2001) performance refers to those attitude that have been assessed or measured as to their contribution to organizational goals. Some studies have used subjective measures to evaluate firms performance, such as employee satisfaction, executives perception about the company's performance absenteeism, employee commitment and other behavior aspects.

The concept of performance has also been expressed by Brumbrach (1988) as follows: performance means both behaviours and results. Behavior emanate from the performer and transform performance abstraction to action. Not just the instrument for results, behaviours are also outcome in their own right the product of mental and physical effort applied to task and can be judged apart from the results.

This definition of performance leads to the conclusion that when managing performance both inputs (behaviours) and outputs (results) need to be considered. It is not a question of simply Considering the achievement of target as used to happen in management by objective schemes, competency factors need to be included in the process (Armstrong, 2006).

Campbell (1999) opines that performance as behavior or action is relevant to the attainment of an Organization goal that can be scaled that is measured. Other studies reference various objective measures for evaluating firm performance such as financial and market indicators. As a result there is no common theory concerning organizational performance and researchers utilize different indicators or variables to measure this construct.

For this reason there is also a call for a precise theory of organizational performance (Janssens and Steyaert, 2009). A theory of performance is necessary to determine relevant dimensions of performance, performance standards or expectations related to performance levels, restrictions on how the situation should be measured when assessing performance, the number of performance level or graSdient and the extent to which performance should be based upon absolute vs relative comparison standards (Boxall, Purcell and Wright, 2007). However for this study organizational performance would be conceptualized using the following factors to measure performance. (i Quality of work (ii Productivity (iii Knowledge of the job (iv Attendance (v Safety and Security

\section{Theoretical Review}

\section{The Theories Reviewed Include the Following}

i Human capital theory by Gary Becker and Jacob Mincer (1994)

ii. Social cognitive learning theory by Albert Bandura (1977)

iii. The cognitive learning theory of Edward Tolman (1886)

\section{The Human Capital Theory}

The concept of human capital is not a new one. It was proposed by Schultz (1975) and later expanded extensively by Becker (1994) based on his research on return - on- investment. Later on, Becker gave the wordings of 'general' and 'specific' human capital (Teixeira, 2002: 
Waldman, 2003) that are widely used by human resources development practitioners worldwide.

The human capital theory suggests that individuals and society derive economic benefits from investments in people (Sweetland, 1996). Becker and Mincer (1994) claim that other things being equal, personal income vary according to the amount of investment in human capital that is, the education and training undertaken by individuals or group of workers. They are of the view that investments in human capital are much more beneficial than those of physical capital therefore should grow at a rate that is equal to if not higher than the rate of investment in physical capital. The origin of the human capital goes back to the emergence of the classical economics in 1776. Since then, there has been monumental interest in human capital both as a concept and theory. According to Schultz (1975), human capital theory rests on the assumption that formal education is highly instrumental and even necessary to improve the production capacity of the works. According to the theory, It refers to the amount spent on training and development, education, among other investments in capital which are being made on human translates to improved performance. Becker (1994). mentioned three viewpoints of categorizing human capital, which is based on the individual aspect of human capital itself, the accumulation process of it, and the production oriented perspective of human capital.

\section{Social learning Theory}

The theory was proposed by Albert Bandera in 1977, he opined that most human behaviour is learned observationally through modeling, from observing others one forms an idea of how new behaviours are performed and on later occasions this coded information serves as a guide for action. The author postulates that learning would be exceedingly laborious, not to mention hazardous, if people had to rely solely on the effects of their own actions to inform them what to do. It recognizes the importance of observing and modeling the behaviours, attitudes, and emotional state of others. The integrative theory of learning explains that people learn through observation and direct experience. The modeling symbolism and self control are the important techniques of social learning. It is a behavioural theory.

\section{Cognitive Learning Theory}

Cognitive learning theory was proposed by Edward (1886), an American psychologist. This theory explains "learning as internal mental process". Learning activities need to focus on building intelligence and cognitive learning is brain based learning (Buckley, 1990). The cognitive revolution is the name of an intellectual movement in the 1950's that began with what is known collectively as the cognitive science. It began in the modern context of greater interdisciplinary communications and research. Cognitive theorist consider that learning is achieved by thinking about the perceived relationship between events and individual goals. The processes within which individuals concerned receives, preserve and interpret information makes the individual learn new behaviour patterns. The relevant areas of interchange were the combination of psychology, anthropology, and linguistics, with approaches developed within then - nascent of artificial intelligence computer science and neuroscience.

This study reviewed three theories that are relevant to this research work, but the human capital theory was adopted to provide explanatory framework because, according to the theory the amount spent on training and development, education and specific acquisitions of knowledge skills and work attitudes are investments in capital which are being made on 
human beings. Training and development programmes provided for employees surely improves the knowledge, skills, and competency of the employees which ought to translate to improved organizational performance.

\section{Methodology}

In view of the nature and scope of this study, this research is limited to the staff of De United foods industries limited at Otta Ogun State. The survey research method was employed and. systematic random sampling technique was used to draw sample from the population of 700.The source of data were primary and data were collected through questionnaire administration. The questionnaire was formatted on a 4 - point likert scale format. A sample of 248 randomly selected respondent from a population of 700 De United food employees at the industrial area of the company at Ota Ogun State. The validity of the research instrument was ascertained by experts in measurement and evaluation from the department of psychology and department of industrial relations and personnel management, Lagos State University,Ojo. The instrument. was subjected to a pilot study using test-re-test methods and a reliability coefficient of 0.75 was Obtained.The sample size of 248 was determined from the population using Krejcie and Morgan sample size determination formular.

Two hundred and forty eight (248) copies of the questionnaire were administered 204 (82.3\%) were duly completed and returned while $44(17.7 \%)$ were not usable. The questionnaire were administered with the help of the human resource officer and some of the employees in human resource department to people in the area of study within seven days interval. The questionnaire were administered to the following categories of employees, supervisory, managers, and senior management staff. Regression was used to analyse data using the SPSS (20.0) version.

\section{Hypothesis 1.}

Training and development has no effect on organizational performance.

\section{Hypothesis 2.}

Organizational learning has no effect on organizational performance.

ANALYSIS OF RESULT

\section{Hypothesis 1}

Table 1

Descriptive Statistics

\begin{tabular}{|l|l|l|l|}
\hline & Mean & Std. Deviation & N \\
\hline $\begin{array}{l}\text { Organizational } \\
\text { Performance }\end{array}$ & 3.9600 & .76 & 204 \\
Training Development & 4.1533 & .72 & 204 \\
\hline
\end{tabular}


Table 2

Model Summary

\begin{tabular}{|l|l|l|l|l|}
\hline Model & $R$ & R Square & $\begin{array}{l}\text { Adjusted } \\
\text { Square }\end{array}$ & $\begin{array}{l}\text { Std. Error of } \\
\text { the Estimate }\end{array}$ \\
\hline 1 & $.679^{\mathrm{a}}$ & .461 & .395 & .75665 \\
\hline
\end{tabular}

(Constant), Training Development

The result of the data analysis shows that there is $67.9 \% \%$ strong and poitive relationship between Organizational performance and Staff training and development. The coefficient of determination which is the $\mathrm{R}^{2}$ shows that $46.1 \%$ variation in organizational performance is explained by training and development while other factors not mentioned account for the remaining $53.9 \%$.

\section{Table 3}

ANOVA $^{\mathrm{a}}$

\begin{tabular}{|ll|l|l|l|l|l|}
\hline \multicolumn{2}{|l|}{ Model } & $\begin{array}{l}\text { Sum of } \\
\text { Squares }\end{array}$ & & Mean Square & F & Sig. \\
\hline \multirow{2}{*}{1} & Regression & 1.027 & 1 & 1.027 & 1.794 & $.043^{\mathrm{b}}$ \\
& Residual & 84.733 & 148 & .573 & & \\
& Total & 85.760 & 149 & & & \\
\hline
\end{tabular}

The F-value is 1.794 at $5 \%$ confidence interval and $p<0.05$. This indicates that the model is statistically significant, therefore the null hypothesis is rejected while the alternative hypothesis is accepted.

\section{Table 4}

Coefficients $^{\mathrm{a}}$

\begin{tabular}{|c|c|c|c|c|c|c|}
\hline \multirow{2}{*}{\multicolumn{2}{|c|}{ Model }} & \multicolumn{2}{|c|}{$\begin{array}{l}\text { Unstandardized } \\
\text { Coefficients }\end{array}$} & $\begin{array}{l}\text { Standardized } \\
\text { Coefficients }\end{array}$ & \multirow[t]{2}{*}{$\mathrm{T}$} & \multirow[t]{2}{*}{ Sig. } \\
\hline & & B & Std. Error & Beta & & \\
\hline \multirow{4}{*}{1} & (Constant) & 3.482 & .362 & & 9.609 & .000 \\
\hline & TRAINING & & & & & \\
\hline & & 115 & 086 & 109 & 1.339 & .033 \\
\hline & $\begin{array}{l}\text { DEVELOP } \\
\text { MENT }\end{array}$ & & & & & \\
\hline
\end{tabular}

a. Dependent Variable: Organizational performance

The result shows that the standardized coefficients of Training Development is positive. Here we are concerned in comparing the contribution of independent variable to the dependent variable, therefore we will use the beta value of the standardized coefficients. The beta value of training and development is .109 and this indicates there is a direct relationship between training and development and organizational performance. That is, as training and development increases, organizational performance increases.

The Sig. value shows that Training Development is statistically significant to the dependent variables and this is because the Sig. value is greater than 0.05 


\section{Hypothesis 2}

\section{Descriptive Statistics}

Table 6

\begin{tabular}{|l|l|l|l|}
\hline & Mean & Std. Deviation & N \\
\hline $\begin{array}{l}\text { Organizational } \\
\text { performance } \\
\text { Organizational } \\
\text { Learning }\end{array}$ & 3.9600 & .75866 & 204 \\
\hline
\end{tabular}

Table 7

Model Summary

\begin{tabular}{|l|l|l|l|l|}
\hline Model & $R$ & R Square & $\begin{array}{l}\text { Adjusted } \\
\text { Square }\end{array}$ & $\begin{array}{l}\text { Rtd. Error of the } \\
\text { Estimate }\end{array}$ \\
\hline 1 & $.250^{\mathrm{a}}$ & .063 & .017 & .76118 \\
\hline
\end{tabular}

The result of the data analysis shows that there is a $25 \%$ weak relationship between Organizational performance and organizational learning. The coefficient of determination which is the $\mathrm{R}^{2}$ shows that $1.7 \%$ variation in organizational performance is explained for by organizational learning while other factors not explained for account for $93.7 \%$.

\section{Table 9}

ANOVA $^{\mathrm{a}}$

\begin{tabular}{|ll|ll|l|l|l|l|}
\hline \multicolumn{2}{|l|}{ Model } & $\begin{array}{l}\text { Sum of } \\
\text { Squares }\end{array}$ & & Mean Square & F & Sig. \\
\hline \multirow{2}{*}{1} & Regression & .009 & 1 & .009 & .016 & $.901^{\mathrm{b}}$ \\
& Residual & 85.751 & 148 & .579 & & \\
& Total & 85.760 & 149 & & & \\
\hline
\end{tabular}

a. Dependent Variable: Organizational Performance

b. Predictors: (Constant), Organizational Learning

The F-value is 0.16 at $5 \%$ confidence interval and $p>0.05$. This indicates that the model is not statistically significant, therefore the null hypothesis is accepted.

\section{Table 10}

Coefficients $^{\mathrm{a}}$

\begin{tabular}{|ll|l|l|l|l|l|}
\hline \multicolumn{2}{|l|}{ Model } & \multicolumn{2}{|l|}{$\begin{array}{l}\text { Unstandardized } \\
\text { Coefficients }\end{array}$} & $\begin{array}{l}\text { Standardized } \\
\text { Coefficients }\end{array}$ & T & \multirow{2}{*}{ Sig. } \\
\cline { 2 - 5 } & $\mathrm{B}$ & Std. Error & Beta & & \\
\hline \multirow{2}{*}{1} & $\begin{array}{l}\text { (Constant) } \\
\text { Organizational } \\
\text { Learning }\end{array}$ & 3.970 & .104 & & 38.238 & .000 \\
& -.002 & .019 & -.010 & -.125 & .901 \\
\hline
\end{tabular}

a. Dependent Variable: Organizational performance

The result shows that the standardized coefficients of Organizational Learning is negative. The concern here is comparing the contribution of independent variable to the dependent 
variable, therefore the beta value of the standardized coefficients was used. The beta value of organizational learning is - .010 and this indicates there is an inverse relationship between organizational learning and organizational performance. That is, as organizational learning decreases, organizational performance increases.

The Sig. value shows that Organizational Learning is not statistically significant to the dependent variables and this is because the Sig. value is greater than 0.05

\section{Discussion of Results}

It was found in this study, that there is $67.9 \%$ strong and positive relationship between organizational performance and staff training and development. The result indicates a .109 beta value standardized coefficient, which shows that there is a direct relationship between training and development and organizational performance, which implies that as training and development increases organizational performance increases. The study also revealed that training and development is statistically significant to organizational performance because the $\mathrm{f}$-cal $>\mathrm{f}$-tab which is significant at 0.05 given a $P=0.43$. This results corroborates with previous studies (Ezeanokwasa,2014; Agwu and Ogiriki, 2014; Obi-Anike and Ekwe,2014) that found a significant and positive relationship between training and development and organizational performance. The result of the hypothesis two showed that there is no statistical significant relationship between organizational learning and organizational performance. The study further revealed that organizational learning determines $6.3 \%$ of organizational performance while other factors not explained for account for $93.7 \%$. The beta value of organizational learning is -010 and this indicates there is an inverse relationship between organizational learning and organizational performance. The study further revealed that organizational learning is not statistically significant to organizational performance because the Fcal < Ftable which is significant at 0.05 given $\mathrm{P}=0.901$.

\section{Conclusion}

The study concluded that there is a strong and positive relationship between training and development and organizational performance.The study further revealed that training and development account for $46.1 \%$ of organizational performance while other factors not explained account for $53.9 \%$ of organizational performance, which shows there is a significant relationship between training and development and organizational performance. The study further revealed the potency of training and development to predict organizational performance which implies that as training and development increase organizational performance increase at De United Foods Industries Limited. However organizational learning account for $6.3 \%$ of organizational performance while the remaining $93.7 \%$ of other factors not explained for account for organizational performance. The study also revealed the impotency of organizational learning to be -.010 and this indicate that there is an inverse relationship between organizational learning and organizational performance, that is as organizational learning decreases organizational performance increase at De united foods and Industries limited. The study concludes that a positive and significant relationship exist between training and development and organizational performance while a non significant and inverse relationship exist between organizational learning and organizational performance. The implication of this is that not all human resource development practices have a direct and significant relationship with organizational performance. 


\section{Recommendations}

Based on the findings and the conclusions drawn from this study on Human resource development, and organizational performance, the following recommendations were made.

i. Organizations should take training and development of employees serious as a way of improving on organizational performance and having sustainable competitive advantage.

ii. Firms should imbibe the culture of budgeting for training at the beginning of every financial year.

iii. Organizations should consider creating collaborative partnerships with public and private training institutions to enhance Organizational Performance.

iv. Organizations should diligently identify training gaps and needs before embarking on any training programme.

v. Organizations should view training broadly as a way of creating intellectual capital, which includes basic skills (skills needed to perform ones job)advanced skills(such as how to use technology and to share information with other employees).

\section{Suggestion For Further Studies}

i. Further studies should be conducted in other sectors such as banking, telecoms among others using other indicators to measure organizational performance.

ii. Studies should be conducted using other indicators of human resource development practices eg (educational opportunities) among others.

\section{References}

Agwu, M., \& Ogiriki, T. (2014) Human resource development and organizational Performance in the Nigeria liquefied natural gas company limited bonny, Journal of Management and Sustainability 4(4) $134-146$

Alan, N., Robert, C., \& Mariam, C. (2002) Strategic human resources management. UK: Southbank Victoria Thomson.

Alchain, A., \& Demsetz, H. (1972) Production information costs, and economic organization. American Economic Review, 62 (3), 777-795.

Aliyu, M., \& Suhal, K., \& Suriyani, M (2014) Investing in human resources development: Empirical evidence form banking Institutions of Malaysia and Nigeria, Journal of Economics and Substance Development 5(2),150-162

Antia, J., \& Cuthbert, R. (1976). Critical. success factors in polytechnic performance, Educational Management Administration and Leadership 5 (14), $14-36$.

Armstrong, M. (2006). A handbook of human resource management practices.UK: Cambridge University Press.

Baloluck, A., \& Buelens, M. (2008) A two-level competing values approach to measure nonprofit organizational effectiveness, Faculty of Economics and Business Administration, Ghent University, Belgium

Becker, G. (1994) Human capital: A theoretical and empirical analysis with special reference to education. United states: university of Chicago Press.

Benjamin, A. (2011) An assessment of human resources development climate in rwanda Private Sector Organizations, International Bulletin of Business Administration, 3(12), 56-68

Brumbach, G. (1988). Some ideas, issues and predictions about performance management. Public Personnel Management. 2 (6) 387-402. 
Buckley, R., \& Caple, J. (1990). The theory and practice of training. London: kogan page Campbell, J. (1999). The definition and measurement of performance in the new age. In D.R. Ilgen \& E.D. Pulakos (Eds), The changing nature of performance. Implications for staffing, Motivation, and Development 2(5) 339-429. San Fransisco: Jossey-Bass.

Chien, C., \& Gary N. (2007) Strategic human resource development, Journal of human development, 1, 2 (1 240-253)

Collins, C., Buhalis, G., \& Peters, F. (2003) Enhancing SMTEs business performance through the internet and e-learning platform, Education and Training 459(8) 483-494

Cook, C., \& Hunsaker, P. (2001) The management and organization behaviour ( $3^{\text {rd }}$ Ed). New York, McGraw Hill.

Daniel, E. (2002) Impact of human resources development and organizational commitment on financial sector employees in Nigeria. Scientific annual of the Alexanida loan Cuza University of Lasi Economics Sciences 59 (2), $29-41$

David, F., Jennifer, A., \& Charles A. (1990) Building organizational commitment: A multi firm study, Journal of Occupational Psychology, 63, $245-261$.

De saa - Perez, P., \& Garcia, F. (2002). A resources based view of human resources management and organizational capabilities development international. Journal of human resources management, 13 (1) 123-135

Ezeanokwasa, F. (2014) Human resources development and organizational performance Informational and Knowledge Management, 4(11) 121 - 124

Garavan, T., \& David, O. (1997) New perspectives on skill learning and training a view point Journal of European industrial training, 3 (2) $131-137$

Garavan, T., Cross, C., Wilson, J., Carbery, R. (2012) Training \& development roles and structures in European call centers: The influence of strategic choice, institutional and coevolution process. Thunderird International business review, 54(10) $875-890$

Garavan, T., Shanahan, V., Carbery, R., \& Watson, S. (2016) Strategic human resource development towards a conceptual framework to understand its contribution to dynamic capabilities, Human Resources Development International 2(5) 1 - 18

Garavan, T. (1991) Strategic human resource development, Journal of European Industrial Training, 15 (1) $17-30$.

Gold, S. (1989) Training in organizations needs assessment development and evaluation. New York: Willey

Gustau, R., \& Frances, S. (2000) strategies for success in human development, journal of human development 2 (4), 140-153

Hassan, R. (2014) Training and developing Impact on organizational performance: empirical evidence from oil and gas sector, journal of business and management, 16 (1), 160-172

Hussy, D. (1985) implementing corporate strategy and change using management education and training, Long Range Planning 18(5), 23-37

Janssens, M., \& Steyaert, C. (2009). HRM and Performance: A Plea for reflexivity in HRM Studies. Journal of Management Studies, 46 (1), 143-155.

Javad, E., \& Davood, G. (2012) organizational commitment and job satisfaction, ARPN Journal of Science and Technology 2 (2), $85-91$

Khalid, R. (2014) strategic role of Human resources development in employee skill developments: An employer's perspective, Journal of Human Resources Management 2 (1) 140-152

Lee, R. (1996). What makes training pay? Issues in people management, London: Institute of Personnel Development, . 
Megehee, W., \& Thayer P. (1961) Training in business and Industries. New York: Willey.

Meyer, J., \& Allen, N. (1991). A three component of organizational commitment. Human Resources Management Review . (1) 61 - 89.

Mohammed, I. (2016). Personnel performance evaluation: a conceptual index for the management and development of Nigeria oil and gas industry: Petroleum training journal 3 (1) $24-31$.

Muhammed, N., Ismail, M. (2009). Intellectual capital efficiency and firms performance study on Malaysian financial sectors, International Journal of Economics and Finance, 1 (2): $206-212$.

Nada, T., Katarian, B., \& Kristyan, B. (2012) the relationship between human resources development and job satisfaction, Management knowledge and learning international conference.

Naveed, A., Nadeen, I., \& Naqui, H. (2014) Impact of organizational commitment and employees performance on the employee satisfaction, International Journal of Learning, Teaching and Educational Research, (1) 84-92.

Nolan, C., \& Caravan, T. (2016) Human resource development in SMES: A systematic review of literature, international journal of management review, 18 (3) 85- 107.

Obi-Anike, H., \& Ekwe, M. (2014) impact of training and development on organizational effectiveness: evidence from selected public sector organizations in Nigeria. European Journal of Business and Management, 6 (29) 66-75

Okoye, P., \& Ezejifor, R. (2013) The effect of human Resources development on organizational productivity, International Journal of Academic Research in Business and Social Sciences, 3(5) $250-268$

Olayemi, S. O. (2012) human Capital Investment and Industrial productivity in Nigeria, International Journal of Humanities and Social Science 2 (16) 298 - 307.

Oyedijo, A. (2004) Strategic management an introductory text. Ibadan Mokola: Adewale printers.

Paprock K., Yumol, B., \& Atienza, T. (2006) National human resource development in Transitioning Societies in the developing world: the Philippines: Advances in developing human Resources 8 (1) $46-61$.

Pauline, J. (2009)Leadership and organizational effectiveness, lessons to be drawn from education, Journal of Nursery Management 17 (1) 54-67.

PoHu. (2007).Theorizing strategic human resource development: Linking financial performance and sustainable competitive advantage University of Minnesota.

Pounder, J. (1999) Organizational effectiveness in higher education. educational management administration \& leadership, 27 (4), 389-400.

Rodriquez, L., \& Chincholkar, A. (2005) Benchmarking the human resources practices of an engineering institute with public sector industry for performance enhancement International Journal of Training and Development 9 (1) 6 - 20

Rogers, E., \& Wright, P. (1998). Measuring organizational performance in strategic human resource management: problems, prospects and performance information markets. Human Resource Management Review, 8 (3), 311.

Roseline, O. (2011) Globalization and human Resource development in Nigeria: American Journal Of Social and Management Science 2, 217-219.

Schultz, T. (1975) Investments in the schooling and health of women and men quantities and returns, Journal of Human Resources 28, 78- 92 (1). 
Swanson, R. (1995). Human resources development Performance is the key. Human Resources Development International Quarterly 6 (2) 207 - 213.

Swanson, R. (2001) Human resources development and its underlying theory, Human resource development international, 4 (3) $299-312$.

Sweetland, S. (1996) Human capital theory: foundations of a field of Inquiry, Review of Educational Research 66(3) $341-359$

Tichy, N., fombrun, C., \& Devanna, M. (1982) Strategic human resource management, Sloan Management Review, Winter, 3 (5), 47-61 